\title{
A PROPOSAL FOR CONSTRUCTING AN ISLAMIC MONEY MARKET FUND FOR THE TURKISH MARKET
}

\author{
Sinan OKUMUŞ
}

\begin{abstract}
Islamic finance is widely considered to be underutilized in Turkey. One of the reasons is the lack of proper investment vehicles to cater the need of investors with interest sensitivity. Participation banks only offer time deposit accounts with more than 30 days maturity. Investors with shorter term liquidity are facing with leaving their money in demand deposit accounts and losing alternative return or moving to the conventional investment vehicles. In this article, we propose to construct an Islamic money market fund in order to protect capital and provide some return for the corporate and individual investors with interest sensitivity. In this context we expect that Islamic money market fund would also help the growth of Islamic finance in Turkey.
\end{abstract}

Keywords: Finance, Islamic Finance, Money Market Funds, Islamic Money Market Funds, Turkish Lease Certificates, Sukuk, Participation Banks.

Jel Codes: G230, G240, G290.

\section{TÜRKIYYE'DE İSLAMİ PARA PIYYASASI FONU KURULMASI İÇİN BİR ÖNERI}

\section{Öz}

İslami finansın Türkiye’de potansiyelinin altında kaldığı görülmektedir. Sebeplerden bir tanesi de faiz duyarılı̆ğı olan yatırımcıların ihtiyaçlarını karşılayacak uygun yatırım araçlarının eksikliğidir. Katılım bankaları yalnızca 30 gün üzerinde vadeli katılım hesabı açabilmektedirler. Kısa dönem için nakdi olan yatırımcılar, paralarını vadesiz hesapta tutarak alternatif getiri kaybına uğramak veya konvansiyonel yatırım araçlarına geçiş yapma ile karşı karşıya kalmaktadırlar. Bu makalede faize duyarlı kurumsal ve bireysel yatırımcılar için anaparayı koruyacak ve bir miktar getiri sağlayacak İslami para piyasası fonu kurulması

* Assistant Professor. Gedik Üniversitesi Gedik Meslek Yüksekokulu , Menkul Kiymetler ve Sermaye Piyasası Bölümü, Email:sinan.okumus@gedik.edu.tr 
önerilmektedir. Bu anlamda İslami para piyasası fonunun ayrıca Türkiye’de İslami finansın gelişmesine katkıda bulunacağı beklenmektedir.

Anahtar Kelimeler: Finans, İslami Finans, Para Piyasası Fonları, İslami Para Piyasası Fonları, Türkiye Kira Sertifikaları, Sukuk, Katılım Bankaları.

Jel Kodları: G230, G240, G290.

\section{Introduction}

Islamic Finance, largely represented by the Participation Banks in Turkey constitutes a mere \%5.15 of total banking assets according to August 2015 data of Banking Regulation and Supervision Agency (BRSA). It has been 30 years since the first Participation Bank was introduced (Okumus, 2014), however Islamic Finance is widely considered to be under-utilized such that the government recently acted to establish state owned Participation Banks (Vizcaino, 2014, p.1).

A recent workshop organized by BRSA and Turkish Participation Banks Association on Participation banks and Interest- Free finance concluded that products, services and markets have not been adequately diversified and developed. The other problems of the sector are noted as lack of sound perception management towards the interest-free finance, lack of adequate human resources and inadequate corporate and legal infrastructure.

Sector participants in the workshop also acknowledged that there should be time deposit accounts (time participation accounts) maturing in less than 30 days (legal minimum time) for some certain amount and maturity.

No time deposit less than 30 days rule causes corporate and individual clients with interest sensitivity and needing their money in less than 30 days for their liquidity management to opt one of the two routes. The first route is to go to a conventional bank for an overnight or some other maturity date repurchase (repo) agreement, or for a time deposit account maturing in a chosen time period, or for a liquid / short term bond and bills fund, disregarding their interest sensitivity. The other route for the interest sensitive clients is to leave the money into a checking account in a participation bank thus having no return for the period.

Participation banks benefit from the money deposited into checking accounts with no cost and increase their profitability. However the clients would be losing money in real terms in an environment with an average Consumer Price Inflation of 8,21\% in between 2004-2014 according to Turkish Statistical Institute data.

Turkish Banking Sector August 2015 Bulletin of BRSA indicates that the ratio of Turkish lira based checking account to total deposits was 18,60\% in non-participation deposit banks versus $23,77 \%$ in participation banks. Such data indicate that due to the lack of a money market 
investment vehicle with a shorter maturity than 30 days is forcing corporate and individual clients with interest sensitivity to leave their money into checking account. Also it is highly possible that there would be a considerable leakage to the conventional financial system due to the lack of proper Islamic products for Islamic investors.

In order to contribute to Islamic Finance in Turkey, we propose construction of Islamic money market funds as an investment product to keep the clients within the non-interest finance system and also earn back the clients who are using conventional banking system due to lack of the proper Islamic investment products.

Money market funds are defined as preserving the investment amount by using cash equivalent investment products with low risk and return. The size of the money market funds in Turkey is equivalent to 27,2 billion lira according to the web site fonmarket.com. Total investment funds market consists of 34,9 billion lira. Given that the money market funds constitute $78 \%$ of the investment funds market.

Islamic money market funds aim to provide liquidity and regular income as their conventional peers. Yet Islamic money market funds invest in short term Islamic bonds and bills, Islamic bank deposits, Islamic reverse repurchase agreements (rrepo-i), buy and sell back agreements on Islamic bonds and bills, and other Islamic investment products.

In this article we tried to construct the mechanics of an Islamic money market fund of which we think it will contribute to the growth of the Islamic finance system in Turkey.

\section{Islamic Finance in Turkey}

Islamic finance has started in Turkey with the foundation of the first Participation (Islamic) bank in 1985 (Okumuş, 2014, p.20). Islamic finance sector is largely represented by the Participation banks. According to the BRSA data there are five Participation banks (one being State bank) with a total asset size of 120,95 billion lira which is $5,15 \%$ of the total banking system assets as of August 2015. Two more State Participation banks are scheduled to operate within the upcoming years (Vizcaino, 2014, p.1).

Islamic finance has been consisted of only Participation banks for a long time and the other areas of the system like life, non-life insurance, brokerage, asset management, investment funds and other Islamic financial products have been largely ignored. However companies were established to address the need in these areas of Islamic finance within the recent years. (Okumus, 2010, p.1)

A recent survey in Turkey Islamic finance report 2014 of Zawya Islamic finds that there is a sizeable interest in participation banking by those currently not using it. Some 38\% of nonparticipation bank clients interested in participation banking. Their interest was strong even with low returns yet not to the extent of capital risk. We can conclude that there is a high growth potential for the Islamic finance. 
Islamic finance sector professionals expect the size of the Participation bank assets to reach $15 \%$ of the whole banking assets in the long run (Katılım Bankacilığ ve Faizsiz Finans Çalıştayı, 2013, pp 93-95).

Turkish government has been very active in supporting the growth of the Islamic finance. The government has been implementing a roadmap by founding State participation banks and paving the way for the lease certificates (Islamic debt instruments).

Islamic debt instruments are vital for the Islamic finance to develop. Lease certificates being asset based and paying rent instead of interest comply with the tenets of Islamic Bonds which is commonly known as Sukuk. The first U.S. dollar denominated lease certificate launched in 2010 (Uyan, 2011, p.10). Turkish lira denominated lease certificates came in 2013 according to the Turkey Islamic Finance report 2014.

On the public side Turkish treasury has started issuing Public Lease Certificates denominated in Turkish Lira and U.S. Dollar which are designed to comply with the Islamic Law since 2012. The Treasury aims to diversify the borrowing instruments, attract a broader base of investors and fulfill the investment needs of the Participation Banks, corporations and individuals who are sensitive to interest.

Borsa Istanbul data indicates that 6,5 billion Turkish lira and 3,75 billion U.S. Dollar denominated public lease certificates are currently in circulation. Also private sectors borrowings through lease certificates total to 862 million Turkish lira.

\section{Money Market Funds in Turkey}

Turkish fund market is consisted of investment funds, pension funds and Exchange Traded Funds. Total number of the funds is 572 with 76,3 billion Turkish lira under management. Investment funds constitute $45,76 \%$ of the total funds with 34,9 billion Turkish lira according to web site fonmarket.com data. Capital Markets Board's data on investment funds indicate a total growth rate of $36,29 \%$ increase on asset under management for the period of $2004-2014$. The number of the fund investors has increased $24,49 \%$ from 2.632 .462 to 3.277 .226 within the same period of time.

Investment funds are classified as Money Market Funds, Bond \& Bills Funds, Balanced Funds, Equity Funds, International Funds, Hedge Funds, Private Funds, Funds of Funds and Commodity Funds. Money Market Funds are fragmented into two groups. One being the liquid funds with duration in between 0-45 days and the other being Short Term Bonds \& Bills Funds with duration in between 45-90 days (fonmarket.com).

There are 66 money market funds with 27,2 billion Turkish lira constituting $78 \%$ of the investment fund market. Money market funds invested $32,11 \%$ of their assets in reverse repurchase agreements, 59,27\% of their assets in short term bond / bills and 8,6\% of their assets in other investment instruments (fonmarket.com). CMB regulates funds' maximum total 
expense ratios (TER) as 1,28\% for the liquid funds and 2,19\% for the Short term bond \& bills funds (CMB,2013, p.23). Money market funds are suitable for short term investments of risk averse investors. Investors mainly use money market funds for daily liquidity management and protection against inflation.

\section{Islamic Money Market Funds}

Islamic funds globally constitute $4 \%$ of the total Islamic assets (Pwc, 2013, p.6). Asset under management reached 75,8 billion US Dollar in 2014 (Inceif,2015, p.1). The market is largely dominated by Saudi Arabia and Malaysia which together holds $65 \%$ of the Islamic fund market according to the web site of Islamicfinance.com.

Islamic money market funds comprise $22,2 \%$ of the assets under management of global Islamic funds. Unlike other global Islamic funds money market funds generally domiciled in home country rather than the offshore domiciles (Paldi, 2015, p.37).

Money market funds invest in low risk securities with less than one year maturity period. The securities invested have high liquidity. The fund charges lesser fees than the funds. The management of the fund is mostly seen as operational rather than investment management.

Islamic money market funds invest in short term Islamic bonds and bills, Islamic bank deposits, Islamic reverse repurchase agreements (rrepo-i) and / or buy and sell back agreements in Islamic fixed income securities and other Islamic investment vehicles all of which with high liquidity and less than one year maturity. The very basic aim of those funds is to preserve the capital and provide positive return within the time. An Islamic money market fund is suitable for investors who require Islam compliant investment vehicles, high level of liquidity, capital preservation, reasonable returns with low risk, and prefers short term investment (RHB Asset Management, 2015, p.53).

Investing in Islamic fixed income securities even for the short maturities causes the fund return to fluctuate and may provide negative returns for daily or weekly periods. In addition to that, lack of liquidity in the secondary market for the bonds leads the fund to face difficulty in redeeming investors' money. Thus fund managers prefer to invest a big portion of the fund assets in rrepo-i and / or buy and sell back agreements in order to avoid return and liquidity issues.

Bank Negara of Malaysia Islamic Banking and Takaful department issued guidance notes on Sell and Buy Back agreement in 2013. According to the notes sell and buy back agreement (SBBA) is an Islamic financial instrument introduced for the purpose of enhancing liquidity in the Islamic Interbank Money Market (IIMM) and providing additional avenue for the IIMM participants to source their funding requirements. The SBBA is akin to the repurchase (repo) agreement and has been modified to comply with Islamic principles. The SBBA mechanism has been approved by the National Shariah Council for Islamic Banking and Takaful of Bank Negara Malaysia. 
"SBBA transactions should consist of commitment by a party to sell securities and the other party to purchase the Islamic securities, and both parties subsequently promise to perform the reversal at a future date and results in transfer of ownership of the transacted Islamic securities under SBBA. The SBBA transactions shall be traded based on price. Ownership of the Islamic securities sold under SBBA shall be transferred from the seller to the buyer. Both parties shall negotiate the terms of SBBA and agreed among others on the type of Islamic securities, SBBA price, tenure and settlement date. The parties shall enter into two separate agreements. First agreement- The SBBA seller sells outright Islamic securities to the SBBA buyer at an agreed price and settlement date. Second agreement- The SBBA buyer promises to sell back the Islamic securities to the SBBA seller whom shall also promise to buy back the instrument at an agreed price and at a future settlement date. The undertaking made by both the buyer and the seller to sell and buy back the instrument respectively at the maturity date of the SBBA shall be based on promise.” (Bank Negara of Malaysia, 2013, p.2,5,7,8).

The Islamic money market funds shall be mainly using SBBA agreements to invest funds' assets. Given that it is imperative to understand the working mechanics of the SBBA agreements. Bank Negara of Malaysia's guidance on the practice of SBBA is very important in order to provide uniformity and standards of the SBBA transactions.

\section{Proposed Islamic Money Market Fund for Turkish Market}

\section{I. Proposed Mechanism}

As aforementioned, money market funds shall invest in highly liquid and short term instruments. Even for the short term treasury bonds and bills, there will be liquidity and price risk depending on the market condition. Therefore fund managers invest a large portion of funds' assets through reverse repo agreements. As for the Turkish market where investors can daily redeem their fund shares, managers mainly get into daily reverse repo agreements in order to avoid liquidity and price risk.

Conventional banks manage their daily liquidity by using Central bank open market repo and reverse repo transactions in addition to other bank transactions. However, participation banks in Turkey had lacked the means of using Central bank open market transactions because those transactions were not Islam compliant. For this reason participation banks were unable to provide return for their excess liquidity.

In order to solve the problem Central Bank of Turkey (TCMB) revised its open market transactions agreement upon the demand from the participation banks and included retraction right from " buying security at a future date for sell buy back transactions" and "selling security at a future date for buy sell back transaction" in favor of the TCMB . TCMB also removed "interest" phrase and replaced with "return". Participation banks started open market transactions with TCMB using public lease certificates as underlying security (TCMB, 2013, p.1,2).

We will implement the same mechanism of the participation banks managing their liquidity for the proposed Islamic money market fund. 
Investment funds sold in Turkish market are heavily regulated by Capital Market Board of Turkey (CMB). CMB requires formation of umbrella funds for funds whose shares are issued under a single statute (CMB, 2013, p.2,3).

The proposed Islamic money market fund will be formed under "Participation Umbrella Fund”. Funds classified under participation umbrella funds may only invest their assets in lease certificates, stock shares, gold or other precious metals and other interest free money and capital market instruments (CMB, 2013, p.3,4).

CMB also defines another umbrella fund type called as "Money Market Umbrella Fund" for funds which can invest in highly liquid money and capital market instruments with a maximum 184 days to maturity and weighted average duration with maximum 45 days (CMB, 2013, p.3)

Either umbrella fund formation can be implemented for the proposed Islamic money market fund structure. We took the former in this study.

The proposed fund will be designed as "Short Term Lease Certificates Fund" complying with $\mathrm{CMB}$ fund regulation. The phrase of "Short term" can only be used if the fund has a weighted average duration between 25 to 90 days (CMB, 2013, p.11).

The fund invests into Turkish lira based short term public and private sector lease certificates, participation time deposit and other interest free Turkish lira based money and capital market instruments. The fund also invests with buy and sell back agreements on lease certificates through Borsa Istanbul. All fund transactions but deposits should be executed in Borsa Istanbul. CMB regulations only allow $10 \%$ of the fund's asset to be executed outside of Borsa Istanbul through repo and reverse repo transactions.

The proposed fund may allocate its assets up to $100 \%$ in public lease certificates, in private sector lease certificates, in buy and sell back transactions of lease certificates and other interest free money and capital market instruments. The fund may only allocate a maximum of $25 \%$ of its assets into participation bank time deposits.

It is important for the fund to be liquid and to provide daily positive return at the same time. For this reason the fund manager would opt to invest a big part of the fund's assets through buy and sell back transactions in order to satisfy both goals above.

The fund will realize buy and sell back transactions as in the case of participation banks or Bank Negara of Malaysia. Both sides (as in Malaysia) or one side (as in TCMB) may retract from its obligation to buy or sell back the underlying security. Such that the agreements should be revised and Borsa Istanbul should act accordingly.

\subsection{Projected Market Size for The Islamic Money Market Funds}

Turkish Banking Sector had 661,3 Billion of Turkish lira based deposits at the end of 2014 . The amount of demand deposits constituted $17,79 \%$ of the total deposits. As for the participation 
banks, total Turkish lira based deposits amounted to 38,8 Billion TL and constituted 23,37\% of demand deposits. Deposit growth in Participation banks exceeded the deposit growth in total banking sector in between 2010-2014.

Table I. Banking Sector And Participation Banks Turkish Lira Based Deposits

\begin{tabular}{|c|c|c|c|c|c|c|}
\hline Million TL & Dec. 2010 & Dec. 2011 & Dec. 2012 & Dec. 2013 & Dec. 2014 & CAGR \\
\hline B anking Sector Turkish Lira Deposit & 433.501 & 459.958 & 520.421 & 594.051 & 661.343 & $11,14 \%$ \\
\hline B anking Sector Turkish Lir a Demand Deposit & 65.201 & 72.177 & 81.462 & 107.244 & 117.676 & $15,91 \%$ \\
\hline Demand Deposit / Deposit & $15,04 \%$ & $15,69 \%$ & $15,65 \%$ & $18,05 \%$ & $17,79 \%$ & \\
\hline Participation B anks Turkish Lira Deposit & 22.119 & 23.896 & 28.408 & 36.567 & 38.838 & $15,11 \%$ \\
\hline Participation B anks Turkish Lira Demand Deposit & 4.164 & 4.887 & 5.201 & 8.592 & 9.076 & $21,50 \%$ \\
\hline Demand Deposit / Deposit & $18,83 \%$ & $20,45 \%$ & $18,31 \%$ & $23,50 \%$ & $23,37 \%$ & \\
\hline
\end{tabular}

Source: Banking Regulation and Supervision Agency

As we observe in Table 2, the ratio of Money Market Funds size to Banking sector demand deposits had diminished between 2010-2014.

Table 2. Money Market Funds vs. Demand Deposits

\begin{tabular}{|c|c|c|c|c|c|}
\hline Million TL & Dec. 2010 & Dec. 2011 & Dec. 2012 & Dec. 2013 & Dec. 2014 \\
\hline B anking Sector Turkish Lira Demand Deposit & 65.201 & 72.177 & 81.462 & 107.244 & 117.676 \\
\hline Money Mark ket Funds & 23.118 & 20.507 & 17.361 & 23.101 & 25.727 \\
\hline MMF/TL Deposit & $35,46 \%$ & $28,41 \%$ & $21,31 \%$ & $21,54 \%$ & $21,86 \%$ \\
\hline
\end{tabular}

Source: Banking Regulation and Supervision Agency and Rasyonet

We project the Islamic Money Market Fund to reach 6.791 Billion TL asset under management at the end of 2025. We used 15\% growth of demand deposits of the Participation banks for the first three years and 10\% afterwards. We also considered Islamic Money market to be $3 \%$ of the demand deposits for 2016 and increased 2\% thereafter. The target is quite in line with current growth rates and also with new Public Participation banks coming to market.

Table 3. Projected Islamic Money Market Funds' Size

\begin{tabular}{|c|c|c|c|c|c|c|c|c|c|c|c|c|}
\hline B & $014 \mathrm{~A}$ & 2015E & $2016 \mathrm{E}$ & $2017 \mathrm{E}$ & $2018 \mathrm{E}$ & 2019E & $2020 \mathrm{E}$ & $2021 \mathrm{E}$ & $2022 \mathrm{E}$ & 2023E & 2024E & $2025 \mathrm{E}$ \\
\hline Banks & 9.076 & 1437 & 003 & 803 & 874 & 255 & 080 & 088 & 297 & 726 & .399 & 32.339 \\
\hline ema & $15 \%$ & $\%$ & $15 \%$ & $15 \%$ & $15 \%$ & $10 \%$ & $10 \%$ & $10 \%$ & $10 \%$ & $10 \%$ & $\%$ & $10 \%$ \\
\hline slami & - & - & $3 \%$ & $5 \%$ & $7 \%$ & $9 \%$ & $11 \%$ & $13 \%$ & $15 \%$ & $17 \%$ & $19 \%$ & $21 \%$ \\
\hline slamic Money Mark et Funds Amount & & - & 360 & 690 & 1.111 & 1.643 & 2.209 & 2.871 & 3.645 & 4.543 & 5.586 & 6.791 \\
\hline
\end{tabular}

Source: Banking Regulation and Supervision Agency and Author 
The proposed Islamic Money Market fund will be distributed through participation banks, conventional banks and brokerage houses and also through Electronic Fund Distribution Platform to the investors. The fund targets corporate investors like pension funds, public trusts, foreign and local companies with interest sensitivity as well as individual investors.

\section{Conclusions}

Turkey targets to become a regional finance hub. Government officials are taking steps to provide this goal. One of the tenets of Turkey becoming a regional finance hub is to establish a strong Islamic finance industry catering the needs of both foreign and local investors with Islamic values.

There is a lack of proper Islamic investment vehicle to address short term investment need of the interest sensitive investors in Turkish financial markets. It is important to invest in short term without enduring liquidity and return problems in an inflationist environment like conventional investors.

In this paper we have tried to set working mechanism of an Islamic money market fund which we expect the corporate and individual investors with interest sensitivity will be investing through. The investors will have both liquidity and positive return for their short term investments.

We project the Islamic Money market funds to reach 6.791 Billion TL asset under management in ten years. In terms of the distribution of the funds, we expect participation banks, conventional banks and brokerage houses to offer the product to their clients. Recently activated Electronic Fund Distribution platform would also help the distribution of the fund to the interested parties.

We also expect that the proposed Islamic money market fund will contribute Islamic finance's growth in Turkey through expanding Islamic designed lease certificate market. 


\section{References}

BERNARDO Vizcaino. Turkey treads fine line as state-run trio eye Islamic banking. p(1) Reuters. Retrieved 2015, October 5 from http://www.reuters.com/article/2014/11/17/turkey-banks-islamicfundsidUSL6N0SJ00N20141117

CAMILLE Paldi (2015). Islamic Funds. p (37). Retrieved 2015, October 12 from http://www.slideshare.net/ CamillePaldi/islamic-funds-1

OKUMUŞ, Sinan (2010). Converting a Conventional Brokerage House into an Islamic One (An Application to the Turkish Market). p (1). $10^{\text {th }}$ Asian Academic Accounting Association Annual Conference.

OKUMUŞ, Sinan (2014). İslami Sigorta (Takaful) Türkiye Uygulaması. p (20). Türkmen Yayınevi

PRICE WATERHOUSE COOPERS (2013). Islamic Finance, Creating Value. p (6).

UYAN, Ufuk. (2011). Faizsiz Bankacılık ve Günümüz Bankacılık Uygulamaları. p(10). İstanbul İktisatçlar Derneği. Retrieved 2014, October 28 from www.ikder.org/sempozyum/Sunumlar4/U.Uyan..ppt

\section{Internet References}

REPUBLIC OF TURKEY PRIME MINISTRY UNDERSECRETARIAT OF TREASURY. Lease Certificate Investor Guide. p (3) Retrieved 2014, October 27 from https://www.hazine.gov.tr/ File/?path=ROOT/Documents/General\%20Content/Lease20Certificates20Guideline.pdf

KATILIM BANKACILIĞI VE FAİZSIZZ FINANS ÇALIŞTAYI. Aralık 2013. p (93,95). Retrieved 2015, October 5 from http://www.tkbb.org.tr/haber-detay/katilim-bankaciligi-ve-faizsiz-finanscalistay-raporu

TURKISH STATISTICAL INSTITUTE (TUIK). Retrieved 2015, October 6 from http://www.turkstat.gov. tr/UstMenu.do?metod=temelist

BANKACILIK DENETLEME VE DÜZENLEME KURULU. Aylık Bülten Ağustos 2015. Retrieved 2015, October 7 from http://ebulten.bddk.org.tr/ABMVC/\#

BORSA İSTANBUL. İșlem Gören Borçlanma Araçlarına İlişkin Veriler. Retrieved 2015, October 9 from http://www.borsaistanbul.com/veriler/verileralt/borclanma-araclari-piyasasi-verileri/piyasaverileri

TURKEY ISLAMIC FINANCE REPORT 2014 (Fundamentals and the Promise of Growth). Zawya Islamic. $\mathrm{p}(102)$. Retrieved 2015, October 9 from https://www.zawya.com/ifg-publications/Turkey250914081540J/

BANK NEGARA MALAYSIA (2013). Guidance Notes on Sell Buy Back Agreement. p (2,5,7,8). Retrieved 2015, October 12 from http://www.bnm.gov.my/index.php?ch=en_reference\&pg=en_reference_ index\&ac $=584$ \&lang=en\#banking

DATASCOPE A.Ş. www.fonmarket.com. Retrieved 2015, October 12 from http://www.fonmarket.com/ piyasa/genel-piyasa-ozeti

ISLAMICFINANCE.COM. Islamic Funds. Retrieved 2015, October 12 from https://www.islamicfinance. com/2015/01/islamic-funds/

RHB ASSET MANAGEMENT (2015). Master Prospectus. p (53). Retrieved 2015, October 12 from http:// www.rhbgroup.com/products-and-services/unit-trust/asset-management/prospectus/

THE GLOBAL UNIVERSITY OF ISLAMIC FINANCE (Inceif), Global Islamic Finance Assets by Market Segment, Retrieved 2015, October 12 from http://www.inceif.org/industry-growth/ 
SERMAYE PIYASASI KURULU (CMB,2013). Yatırım Fonlarına İlişkin Esaslar Tebliği. p $(2,3,4,11,23)$. Retrieved 2015, October 13 from http://www.spk.gov.tr/apps/Mevzuat/?submenuheader=-1

TÜRKIYE CUMHURIYETİ MERKEZ BANKASI (TCMB,2013). Açık Piyasa İşlemleri Talimatlarındaki DeğişikliklerHk.p(1,2).Retrieved2015,October13fromhttp://www.tcmb.gov.tr/wps/wcm/connect/ a03fa0e9-d93c-4fd0-aa2f-52c7d4aaae2b/katbank.pdf?MOD=AJPERES\&CACHEID=a03fa0e9d93c-4fd0-aa2f-52c7d4aaae2b

SERMAYE PIYYASASI KURULU (CMB,2015). Aylık İstatistik Bülteni Mayıs 2015. Retrieved 2015, October 23 from http://www.spk.gov.tr/apps/aylikbulten/index.aspx?submenuheader $=0$

RASYONET (2015). Yatırım Fonları İstatistikleri. Retrieved 2015, October 23 from http://www.rasyonet. com/

ABDUL-RAHMAN, Yahia (1999). Islamic Instruments for Managing Liquidity. International Journal of Islamic Financial Services Vol 1 No 1. Retireved 2016, February 19 from http://kantakji.com/ media/1945/art3.pdf

OLAYEMI, A.A.M.; HASAN, A.; IBRAHIM, U.; YASIN, N.M.; BUANG, A.H. (2015). Islamic Interbank Money Market: A Comparative Legal Study Between Malaysia and Some Notable Jurisdictions. Journal of Islamic Law, Banking \& Finance, Malaysian Current Law Journal, Shariah Reports 1. Retireved 2016, February 19 from http://papers.ssrn.com/sol3/papers.cfm?abstract_id=2690359 
